\title{
Correction to: Long-term survival after hepatectomy for metachronous liver metastasis of pancreatic ductal adenocarcinoma: a case report
}

Chikanori Tsutsumi ${ }^{1}$, Toshiya Abe ${ }^{1 *}$, Tomohiko Shinkawa ${ }^{1}$, Kazuyoshi Nishihara' ${ }^{1}$ Sadafumi Tamiya ${ }^{2}$ and Toru Nakano ${ }^{1}$

\section{Correction to: Surg Case Rep (2020) 6:157 https://doi.org/10.1186/s40792-020-00924 $-8$}

Following the publication of the original article [1], an error was identified in the "Case presentation" section. The patient's age in the first sentence is currently 69-yearold, however, it should be 51-year-old.

The original article has been corrected.

\section{Author details}

1 Department of Surgery, Kitakyushu Municipal Medical Center, 2-1-1 Bashaku, Kokurakita-Ku, Kitakyushu 802-0077, Japan. ${ }^{2}$ Department of Pathology, Kitakyushu Municipal Medical Center, Kitakyushu, Japan.

Published online: 07 December 2020

\section{Reference}

1. Tsutsumi C, Abe T, Shinkawa T, Nishihara K, Tamiya S, Nakano T. Longterm survival after hepatectomy for metachronous liver metastasis of pancreatic ductal adenocarcinoma: a case report. Surgical Case Reports. 2020;6:157. https://doi.org/10.1186/s40792-020-00924-8.

\section{Publisher's Note}

Springer Nature remains neutral with regard to jurisdictional claims in published maps and institutional affiliations.

${ }^{*}$ Correspondence: t-abe@surg1.med.kyushu-u.ac.jp

1 Department of Surgery, Kitakyushu Municipal Medical Center, 2-1-1

Bashaku, Kokurakita-Ku, Kitakyushu 802-0077, Japan

Full list of author information is available at the end of the article in this article are included in the article's Creative Commons licence, unless indicated otherwise in a credit line to the material. If material is not included in the article's Creative Commons licence and your intended use is not permitted by statutory regulation or exceeds the permitted use, you will need to obtain permission directly from the copyright holder. To view a copy of this licence, visit http://creativecommons.org/licenses/by/4.0/. 